\title{
THE AUTHORITY TO FILE BANKRUPTCY PETITIONS AFTER THE ESTABLISHMENT OF INDONESIA'S FINANCIAL SERVICES AUTHORITY*
}

\author{
Erma Defiana Putriyanti**
}

Faculty of Law, Universitas Nasional Jakarta, Jakarta Selatan

Jalan Sawo Manila, Pejaten, Pasar Minggu, Jakarta Selatan 12520

\begin{abstract}
The transfer in the functions, duties, and authority for regulation and supervision as stipulated in Article 55 of the Act concerning the Financial Services Authority (OJK) does not include the transfer of authority in filing a petition for bankruptcy. The authority to file a bankrupty petition against a debtor in the financial services sector still refers to Article 2 paragraph (3) to (5) Act No. 37 of 2004 concerning Bankruptcy and Suspension of Payment.
\end{abstract}

Keywords: authority, bankruptcy petition, Financial Services Authority.

\section{Intisari}

Peralihan fungsi, tugas dan kewenangan pengaturan dan pengawasan sebagaimana dimaksud dalam Pasal 55 Undang-undang tentang Otoritas Jasa Keuangan (OJK) tidak termasuk peralihan kewenangan pengajuan pailit. Kewenangan untuk mengajukan permohonan pailit terhadap debitor yang bergerak dibidang jasa keuangan tetap mengacu pada Pasal 2 ayat (3) sampai (5) Undang-Undang Nomor 37 Tahun 2004 tentang Kepailitan dan PKPU

Kata Kunci: kewenangan, pengajuan pailit, Otoritas Jasa Keuangan.

\section{Pokok Muatan}

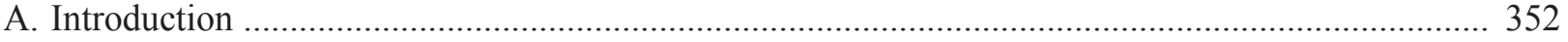

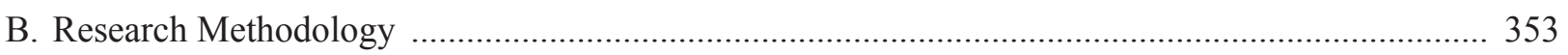

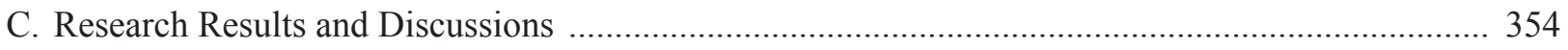

1. The Provisions for Filing a Petition for Bankruptcy according to Article 2 Paragraph (3), (4), and (5) Act No. 37 of 2004 concerning Bankruptcy and Suspension of the Obligation for the

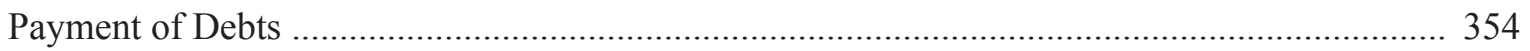

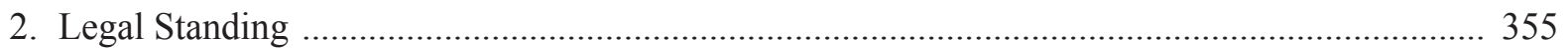

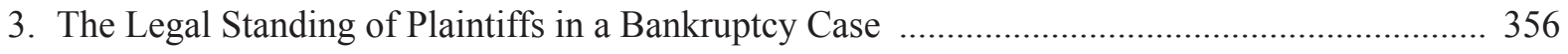

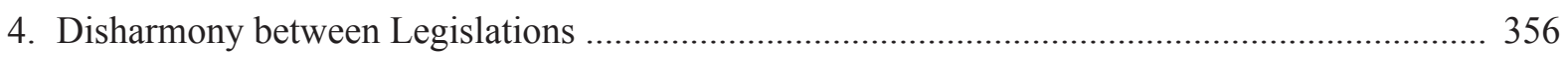

5. The Authority of Bank Indonesia, Minister of Finance, and the Capital Market Supervisory

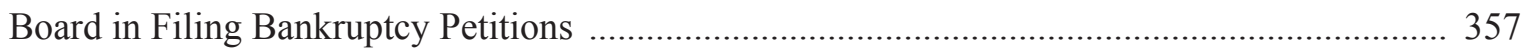

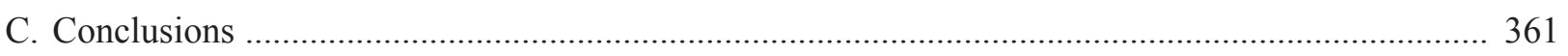

\footnotetext{
* Stimulus Research Results funded by Universitas Nasional Jakarta in 2014.

** Correspondence address: erma_defiana@yahoo.co.id
} 


\section{A. Introduction}

Financial Service Insitituions are institutions carrying its activities in the financial service sector. The financial service activites carried out by financial service institutions include those in the sector of Banking, Capital Market, Insurance, Pension Fund, Financing Institution, and other Financial Insitutions. ${ }^{1}$ Seeing its large scope of activities, it can be said that financial service institutions holds a important role in the national economic system. Before the Financial Services Authority (Otoritas Jasa Keuangan or OJK) was established, the authority to regulate and oversee financial service institutions in Indonesia was held by several separate institutions. The banking sector is supervised by the Indonesian Central Bank or Bank Indonesia, capital market is under the supervision of the Capital Market Supervisory Board, and for insurance, pension funds, financing institutions, and other financial service institutions are under the supervision of the Minister of Finance.

Since the establishment of the Financial Services Authority through Act No. 21 of 2011 (hereinafter referred to as "Financial Services Authority Act"), the function, duties, and authority in regulation and supervision is overall held by the Financial Services Authority. The Indonesian Financial Services Authority or OJK, was established following the rapid development in the field of information technology and the financial innovations which follows, altogether creating a financial system that is more complex, dynamic, and inter-connected with other financial sectors both for its products and institutional forms. Additionally, the presence of financial service institutions and their ownership relations in several financial subsectors (conglomeration) has added to the complexity of transactions and interactions between financial services institutions in the financial system. The large number of cross-sector issues in the financial services sector, including the prevalence of moral hazard, a sub-optimal protection for consumers of financial services, and factors distrupting the stability of the financial system further support the need of establishing an integrated supervising body for the financial services sector. ${ }^{2}$

According to Article 5 of the Financial Services Authority Act, it is stipulated that OJK has the function to implement an integrated control and supervision system towards all activities in the sector of financial service including Capital Market, Insurance, Pension Fund, Financing Institution, and other Financial Insitutions. Through Article 55 of the Financial Services Authority Act, it is determined that since 31 December 2012, the function, duties, and authority of regulation and supervision for financial services activities in the sector of capital market, insurance, pension fund, financing institutions, and other financial services is transferred from the Minister of Finance and the Capital Market Supervisory Board to the Financial Services Authority. ${ }^{3}$ The second paragraph to Article 55 also regulates that from 31 December 2012, the function, duties, and authority in regulating and supervising financial services in the sector of banking is transferred from Bank Indonesia to the Financial Services Authority. It then becomes a question whether the transfer of function, duties, and authority in regulation and supervision includes the authority for the Financial Services Authority to file a petition for bankruptcy for institutions previously under the supervision of Bank Indonesia, the Capital Market Supervisory Board, and Minister of Finance. Humongous

In accordance with Article 2 paragraph (3)(5) Act No. 37 of 2004 concenning Bankruptcy and Suspension of the Obligationg for Payment of Debts (hereinafter referred to as 'Bankruptcy Act'), in the event the Debtor is in the form of a bank, the petition for a declaration of bankruptcy may only be filed by Bank Indonesia. This is mainly because Bank Indonesia is the institution responsible for 
conducting assessments on the overall financial and banking condition before filing for bankruptcy against a bank. In the event the Debtor is in the form of a Securities Company, Stock Exchange, Clearing and Custodian Institution, Settlement and Depository Institution, the petition for a declaration of bankruptcy may only be filed by the Capital Market Supervisory Board. The underlying reason for this is because the aforementioned institutions activities' relates closely to public funds which are invested in the form of securities and is under the supervision of the Capital Market Supervisory Board. Furthermore, in the event the Debtor is in the form of an Insurance Company, a Reinsurance Company, Pension Funds, or State-Owned Enterprises engaged in the sectors of public interest, the petition for a declaration of bankruptcy may only be filed by the Minister of Finance. The provision is needed to build public trust in these institutions as they are risk management institutions and public fund management institutions that plays a strategic role in development and economic life. ${ }^{4}$

From Article 2 paragraph (3) to (5) of the Bankruptcy Act, we could draw that the provisions is intended so that financial institutions which manages public funds must cannot be easily bankrupt and because of this restrictions are necessary. Only specified institutions within Article 2 paragraph (3) to (5) of Bankruptcy Act may file for bankruptcy petitions over financial services institutions. If no restrictions are in place, this may destabilize the national economy.

It is now known that the function, duties, and authority in regulating and supervising financial services has been transferred to the Financial Services Authority from Bank Indonesia, Minister of Finance, and the Capital Market Supervisory Board. However, the Financial Services Authority Act does not specifically provide the effects of such transfer as the Act focuses more on the establishment of OJK as an institutional form, such as its procedures of establishment, organizational structure, and institutional relations. It has yet to be specified whether the provision on the transfer of function, duties, and authority includes also the authority to file bankruptcy petitions. This will bring up a large vacuum where state officials and the public may interperet the law individually as they see fit. Consequently, this will create legal uncertainty for those who want to fight for their rights through the bankruptcy process.

Based on the above discussion, the issue raised in this research will be how Bank Indonesia, Minister of Finance, and the Capital Market Supervisory Board, with the authority they are given with, may file for bankruptcy petitions after the establishment of the Financial Services Authority.

\section{B. Research Methodology}

This research is a descriptive-analytical research, a research which lays down researched facts and further relates them to legislations, theories, opinio iuris, and jurisprudence. The approach uses normative methods; a normative legal research in itself is a scientific research procedure to find truth based on legal logic from its normative perspective. Normative legal research uses firm scientific logic based on scientific disciplines and normative legal underpinnings, namely legal science which places the law itself as the object. ${ }^{5}$

The data collection method used in this research is done through the study of documentation. This is conducted by referring to documented materials by way of studying, reviewing, and examining secondary date, either in the form of books, legislation, legislations, jurisprudence, and legal doctrines which relates to bankruptcy and financial services institutions. Data received from this research is then systematically organized and analyzed through qualitative methods (the method of collecting and selecting data obtained from secondary data including primary, secondary

See Elucidation to Article 2 paragraph (3)-(5) Act No. 37 of 2004 concerning Bankruptcy and Suspension of the Obligation for Payment of Debts.

Johnny Ibrahim, 2006, Penelitian Hukum Normatif, Tribisana Karya, Jakarta, p. 57. 
and tertiary legal materials). The results from the organized data will arrive at an answer to the problem and will be delivered through an elaboration that is descriptive-qualitative in character (an elaboration which depicts the problem and its solution in a clear and comprehensive manner based on data obtained throughout the research).

\section{Research Results and Discussions}

1. The Provisions for Filing a Petition for Bankruptcy according to Article 2 Paragraph (3), (4), and (5) Act No. 37 of 2004 concerning Bankruptcy and Suspension of the Obligation for the Payment of Debts

\section{a. Filing Bankruptcy Petitions accord- ing to Article 2 Paragraph (3) Bank- ruptcy Act}

Article 2 paragraph (3) Act No. 37 of 2004 concerning Bankruptcy and Suspension of the Obligation for the Payment of Debts regulates that in the event the Debtor is a bank, then the petition for a declaration of bankruptcy may only be filed by Bank Indonesia. The elucidation to this article stipulates that the filing of petition for declaration of bankruptcy against a bank that is under the authority of Bank Indonesia shall be based on the evaluation of the overall financial condition and banking condition and, therefore no accountability report is necessary. The authority of Bank Indonesia to file a petition for declation of bankruptcy shall not be prejudice to Bank Indonesia's authority to revoke banking permits, to dissolve legal entities, and to liquidate banks in accordance with the prevailing laws and regulation. According to this paper's author, the logic behind the provision is due to the fact that banks are institutions which manage public funds in the form of deposits and disburse them in the form of credit to the public. If banks can easily file for bankruptcy, this will undoubtely affect public confidence towards banks and public distrusts towards banking institutions will consequently affect the national economy. Because of this, bankruptcy petitions may only be filed by Bank Indonesia. Another reason is because Bank Indonesia is the authority which conducts supervision and guidance towards banks. Bank Indonesia is regarded as an authority which understands the solvability and liquidity of banks as they supervise all of the bank's activities. Banks has the obligation to submit periodic reports to Bank Indonesia, enabling Bank Indonesia to supervise and monitor the condition the bank's financial condition. This Article implicity implies that only banks that are 'unhealthy', illiquid, and has a solvability rate of under $8 \%$ may be filed for a bankruptcy petition by Bank Indonesia.

b. Filing Bankruptcy Petitions according to Article 2 Paragraph (4) Bankruptcy Act

In the event the Debtor is in the form of a Securities Company, Stock Exchange, Clearing and Custodian Institution, Settlement and Depository Institution, the petition for a declaration of bankruptcy may only be filed by the Capital Market Supervisory Board. ${ }^{6}$ The petition of bankruptcy may only be filed by the Capital Market Supervisory Board because the aforemention institutions engage in activities that concerns public funds invested in the form of securities under the supervision of the Capital Market Supervisory Board. The Capital Market Supervisory Board also posseses full authority to file petition for declaration of bankruptcy against institutions under its supervision, much like Bank Indonesia's authority towards banks.

Capital market is one of the factors acting as an indicator to a state's macro- 
economy. Capital market can also be used to asses the condition of companies within a given country as most industries would be represented within it. The capital market contatins market activities where capital owners (investors) with parties needing capitals (companies/capital and bonds seller) meet. The capital market is very sensitive to a given country's issues as well as its turmoils, and this is in turn causes the Stock Price Index to change. Conversely, if a country becomes more stable, their Stock Price Index will also become stable. All activities conducted within the capital market must obtain permission from the Capital Market Supervisory Board, this is because the Board is the body who conducts supervisory, regulatory, and guidance measures in the capital market sector. If institutions in the capital markets could easily file bankruptcy, this may destabilize the market, investors will divest from Indonesia, and could further affect the Indonesian economy. Thus the Article exists to prevent this unwanted outcome, and only the Capital Market Supervisory Board may have the authority to file a petition of bankruptcy.

\section{c. Filing Bankruptcy Petitions accor- ding to Article 2 Paragraph (5) Bankruptcy Act}

In the event the Debtor is in the form of Insurance Company, Reinsurance Company, Pension Funds, or State-Owned Enterprises engaged in the sectors of public interest, the petition for a declaration of bankruptcy may only be filed by the Minister of Finance. ${ }^{7}$ This provision is needed to build public confidence in insurance companies or reinsurance companies as risk management institutions that plays a strategic role in development and economic life.

If those companies can easily file for bankruptcy, this will affect public confidence towards these institutions, and furthermore affect the national economy. Therefore, the authority to file for bankruptcy petitions for those institutions may only be conducted by the authority which conducts supervision and guidance in that sector, namely the Minister of Finance.

\section{Legal Standing}

Indonesian civil law adopts a passive judicial system, whereby judges wait for cases to be submitted unto them. Judges will only examine and decide upon a case when injured parties, whose civil rights have been breached, files a lawsuit. The consequence of having those rights breached by other person(s), is that the injured party(ies) may file a lawsuit to a court so it could be decided and settled through a judge. Therefore, plaintiffs must have the status/capacity to act in accordance to the law, namely persons whose rights have been violated by others.

The word 'legal standing' is derived from the word "Personae Standi in Judicio" which means the right to file lawsuits or petitions in front of of a court of law. ${ }^{8}$ Several literatures state that 'legal standing' is the legal position or authority to file a lawsuit or petition in a court of law. ${ }^{9}$ A person's legal standing in filing for a lawsuit or petition towards a court of law is the most basic matter. If a lawsuit is filed by a person who does not have the right capacity to do so then the lawsuit will be legally be formally defective. Furthermore, if a lawsuit contain formal errors and an Exception is putforth by the defendant, then judge may declare the lawsuit as Niet Onvankelijke verklaard (N.O) or inadmissable. Niet Onvankelijke verklaard (N.O) means that the case does not need to be further examined.

Article 2 paragraph (5) Act No. 37 of 2004 concerning Bankruptcy and Suspension of the Obligation for Payment of Debts.

Harjono, 2008, Konstitusi Sebagai Rumah Bangsa Pemikiran Hukum Dr. Harjono, S.H., M.C.L. Wakil Ketua MK, Sekretariat Jenderal dan Kepaniteraan Mahkamah Konstitusi, Jakarta, p. 176.

Summarized from Rahayu Hartini, 2008, Penyelesaian Sengketa Kepailitan di Indonesia, Prenada Media, Jakarta, p. 14. See also Kartini Muljadi and Gunawan Widjaja, 2005, Pedoman Menangani Perkara Kepailitan-Edisi Revisi, Raja Grafindo Persada, Jakarta, p. 28. 
3. The Legal Standing of Plaintiffs in a Bankruptcy Case

Bankruptcy cases are cases over civil/ private disputes, therefore its settlement is done in accordance to civil procedural law through a commercial court. Within civil procedureal, there exists two types of claims that can be submitted for a judge to decide upon: a lawsuit or a petition. Lawsuit is a letter of claim towards civil rights containing the requested dispute for the judge to decide and settle.Within a lawsuit, there are two or more conflicting parties. Whilst a petition is a right to claim civil rights towards a person's interest and does not need an element of dispute or conflict within it.

Bankruptcy is a special civil case, therefore its contents are not like civil cases in general. In a bankruptcy case, the claim of right submitted to the court is called a petition, however unlike other petitions in civil cases it contains an element of dispute within it namely the dispute over the debts of the applicant and the respondent. Additionally, the legal effect from a declaration of bankruptcy affects the position of the Debtor. For example, after being declared bankrupt, the Debtor -by law- loses their right to manage their own assets, and all of the bankrupt Debtor's assets (except those stated under Article 22 Bankruptcy Act) will fall under general civil forfeiture (gerechtelijk beslag). Based on this, the Bankruptcy Act restrictively regulates and limits parties which have legal standing to file bankruptcy petitions towards certain debtors. Therefore, not all persons may file for a bankruptcy petition towards other persons.

The restriction towards parties which may file bankruptcy petitions has only emerged in the last Bankruptcy Act (Act No. 37 of 2005 concerning Bankruptcy and Suspension of the Obligation for Payment of Debt), within its Article 2 paragraph (3-5). This provision is meant so not everyone may easily file bankruptcy petitions against other persons. If every person has the right to easily file a bankruptcy petition this could fatally affect certain debtors. For example debtors engaged in the financial services sector whose business is to manage funds from the society, namely debtors engaged in capital markets, debtors.

\section{Disharmony between Legislations}

On 22 November 2011, through Act No. 21 of 2011, the Indonesian government established the Financial Services Authority or Otoritas Jasa Keuangan. The Financial Services Authority functions to implement an integrated regulatory and supervisory system towards overall activities in the sector of financial services. ${ }^{10}$ The overall financial services sector includes the activity of financial services in the sector of banking, capital market, insurance, pension fund, financing institutions, and other financial services. ${ }^{11}$ Through Article 55, it is stipulated that from 31 December 2012, the function, duties, and authority in the regulation and supervision of the activities in the financial services sector including capital market, insurance, pension fund financing institutions, and other financial services institutions is transferred from the Minister of Finance and the Capital Market Supervisory Board to the Financial Services Authority. ${ }^{12}$ It also stipulated that from 31 December 2012, the function, duties, and authority over the regulation and supervision of financial services activities in the banking sector is transferred from Bank Indonesia to the Financial Services Authority. ${ }^{13}$ According to these provisions, it can be seen that there has been a transfer of authority in regulation and supervisison from the Minister of Finance, the Capital Market Supervisory Board, and Bank Indonesia to the Financial Services Authority. It then becomes a question whether the transfer of authority includes also the authority to file a petition for bankruptcy?

The Financial Services Authority Act does

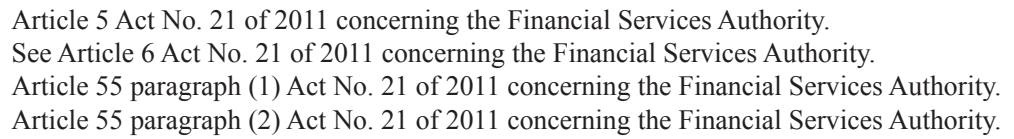


not contain any provision which regulates whether the function, duties and authority as stipulated under Article 55 includes also the authority of the Financial Services Authority to file petitions of bankruptcy against institutions previously under the supervision of Bank Indonesia, the Capital Market Supervisory Board. This has occurred due to the disharmony that exists between legislations, namely the Financial Services Authority Act with the Bankruptcy Act. The disharmony in legislation can cause legal uncertainty for justice seekers. Furthermore, it may cause differing views on interpretation in the legislation's implementation. This will in the future be cause to the ineffectivity of the law and its implementation in the society. At the end the law could no longer function to give guidelines on societal behaviour, social control, dispute settlement and as a vehicle for social change in an orderly and organized manner. The disharmony between legislations is caused among other by: ${ }^{14}$

a. The formation of laws is carried out by different institutions and often in different time periods;

b. The authorized state officials tasked to formulate the legislation changes due to limits in terms, assignment changes, or replacements;

c. The sectoral approach in formulating legislations is stronger than systems approach;

d. Lack of coordination in the process of formulating of legislations which involves several institutions and legal disciplines;

e. Public access to participate in the legislation's formulation process is still quite limited; and

f. The lack of definitive and standard means and methods which bind institutions who has the authority to formulate legislations.

In order to overcome the disharmony between the Bankruptcy Act and the Financial Services Authority Act, the following can be done:

a. Amend certain articles which experience disharmony or all of the articles in the concerned legislation, by the institutions authorized in forming it. In this regard, the amended article is Article 2 paragraph (3-5) Bankruptcy Act

b. Submit a judicial review to the relevant judiciary.

c. Apply the lex specialis derogat legi generalis principle. This principles implies that the specialized law would override the more general law. Bankruptcy cases are special cases, in which there exists a dispute over debts between the debtor and creditor. Therefore if a debtor is unable to resolve its debts towards their creditors due to their financial inability to do so, and a petition of bankruptcy is filed to the commercial court, the case must abide by Act No. 37 of 2004. The following are several principles that must be considered in applying the Lex specialis derogat legi generalis principle: ${ }^{15}$

1) The provisions in the more general law still applies, except when a special provision has been set.

2) The lex specialis provision must be in the same hierarchy as the lex generalis provision (a statutory act with another statutory act).

3) The lex specialis provisions must be under the same legal regime as the lex generalis.

5. The Authority of Bank Indonesia, Minister of Finance, and the Capital Market Supervisory Board in Filing Bankruptcy Petitions

In accordance to Article 55 paragraph (1),

\footnotetext{
14 A.A. Oka Mahendra, "Disharmonisasi Antar Peraturan Perundang-undangan", www.ditjendpp.kemenkumham.go.id, accessed on 5 October 2014.

15 Ibid.
} 
from 1 Januari 2012 with the transfer of function, duties, and authority in regulating and supervising capital markets to the Financial Services Authority, the Capital Market Supervisory Board has institutionally been amalgamated into the Financial Services Authority. Therefore since the existence of Article 55 paragraph (1), the Capital Market Supervisory Board which previously was under the Minister of Finance has been amalgamated into the Financial Services Authority, rendering the inexistence of the Capital Market Supervisory Board. This applies differently with Bank Indonesia; eventhough the duties, function, and authority in regulating and supervising banks has been taken over by the Financial Services Authority in accordance to Article 55 paragraph (2), institutionally Bank Indonesia still exists and is not amalgamated into the Financial Services Authority. The transfer of function, duties, and authority from Bank Indonesia to the Financial Services Authority only concerns those in relation to microprudential supervision. This is evident in the Elucidation to Article 69 paragraph (1) letter a of the Financial Services Authority Act. The duties of Bank Indonesia in regulating and supervising banks as stated within Article 8 letter c transferred to the Financial Services Authority is the regulatory and supervisory duties relating to microprudential. Bank Indonesia is still under the duty to regulate macroprudential banking. ${ }^{16}$

The macroprudential regulation and supervision duty of Bank Indonesia towards banks includes among others: ${ }^{17}$
a. Prevent and reduce systematic risks;
b. Encourage a balanced and of good quality intermediary function; and
c. Improve the efficiency of the financial system and access to finance.

Macroprudential regulations carried out by Bank Indonesia towards banks uses regulatory instruments such as: ${ }^{18}$
a. Strengthen capital resilience and prevent excessive leverage;
b. Manage intermediary functions and control credit risks, liquiditiy risks, foreign exchange risks, interest rate risks, and other risks which would potentially lead into a systematic risk;
c. Limit concentration of exposure;
d. Strengthen financial infrastructure resilience; and/or
e. Improve the efficiency of the financial system and financial access.

Bank Indonesia conducts its macroprudential supervision through the surveillance of the financial system; and by way of conducting examinations towards banks and other institutions in connection with banks when needed. ${ }^{19}$ It can thus be concluded, that based on Bank Indonesia Regulation the transfer of function, duties, and authority as stipulated witin Article 55 paragraph (2) of the Financial Services Act from Bank Indonesia to the Financial Services Authority only relates to the microprudential regulation and supervision of banks from Bank Indonesia to the Financial Services Authority. While for macroprudential regulation and supervision, the authority is still held by Bank Indonesia.

Another question then emerges, whether the authority to file for bankruptcy petitions can be categorized under macroprudential authority. According to the author's analysis, when this is examined furhter it can be seen that the purpose of why the function to conduct macroprudential regulation and supervision towards banks is stil held by Bank Indonesia is due to Bank Indonesia's position as the central bank, therefore the Bank has the task to promote the stability of the monetary/ financial system.

Bankruptcy is a condition where the debtor is unable to pay off and resolve its debts to the creditor. The inability to pay this debt concerns the debtor's situation of insolvency institutionally. Therefore institutionally, the debtor does not have sufficient financial ability to pay off its debts.

\footnotetext{
See Elucidation to Article 69 paragraph (1) letter a, Act No. 21 of 2011 concerning the Financial Services Authority. Article 2 Bank Indonesia Regulation No. 16/11/PBI/2014 concerning Macroprudential Regulation and Supervision.

Article 3 Bank Indonesia Regulation No. 16/11/PBI/2014 concerning Macroprudential Regulation and Supervision.

Article 5 Bank Indonesia Regulation No. 16/11/PBI/2014 concerning Macroprudential Regulation and Supervision.
} 
Consequently, the main cause of bankruptcy is the debtor's 'unhealthy' institutional condition and its financial difficulty. Whilst monetary systems concerns the policies and measures to maintain the stability of exchange rates, for example by limiting the circulation of money, bank interest rates, and ensuring the certainty and flow of financing institutions' liquidity. It can thus be concluded that bankruptcy towards banking institutions is not included in macroprudential regulation and supervision.

In order to clarify the microprudential duties, function, and authority from Bank Indonesia to the Financial Services Authority, Article 7 of the Financial Services Act provides the following:

a. Regulation and supervision concerning banks institutional matters of which includes:

1. Liscense for the establishment of banks, opening of bank's branch office, article of association, working plan, ownerhip, management and human resources, merger consolidation and bank acquisition, as well as revocation of bank business license; and

2. Bank business activity, such as source of fund, fund provision, hybridization product, and activities the field of service;

b. Regulation and supervision concerning the health of bank of which includes:

1. Liquidity, profitability, solvency, asset quality, minimum capital adequacy ratio, maximum limit of credit provision, loan ration towars deposits, bank backup;

2. Bank reports which relate to the health and performance of the bank;

3. Debtor information system;

4. credit testing; and

5. Bank accounting standards;

c. Regulation and supervision concerning the banks precautionary aspects, of which includes:

1. Risk management;

2. Governance;

3 . The principle of know your customer and anti-money launder- ing; and

4. Precautions against the finance of terrorism and banking crimes; and

d. bank inspection(s).

When this is then linked to Bank Indonesia's authority to file petitions for bankruptcy against banks, the results of the research has shown that the transfer of regulatory and supervisory function from the Minister of Finance, Bank Indonesia, and the Capital Market Supervisory Board will not automatically transfer the authority of those institutions to file bankruptcy petitions towards debtors in accordance to Article 2 paragraph (35) Bankruptcy Act. This is because bankruptcy institutions are special institutions which conducts civil forfeiture towards the debtor's assests when the debtor is unable to pay their debts. Therefore, bankruptcy cases are special civil cases which contains disputes over debt. If a debtor is unable to pay their debts and a bankrupty petition is filed then the case will be subject to Act No. 37 of 2004 concerning Bankruptcy and the Suspension of the Obligation for Payment of Debt. Thus if the debtor who will be filed for a bankruptcy petition is a Bank, then according to Article 2 paragraph (3) of the Bankruptcy Act, the party having a valid legal standing as an applicant for filing a declaration of bankruptcy is Bank Indonesia. The same rule applies also to debtors in the form of insurance companies, reinsurance companies, pension funds, and state-owned enterprises engaged in the sector of public interest, based on Article 2 paragraph (5) of the Bankruptcy Act, the party having valid legal standing to do so is still held by the Minister of Finance. Specifically for debtors in the form of securities companies, stock exchange, clearing and custodian institutions, settlement and depository institutions, to determine which institution has legal standing as the bankruptcy applicant it must be requested through a court order first. This is because the Capital Market Supervisory Board has been amalgamated into the Financial Services Authority thus its institutional form no longer 
exists. Therefore, Article 2 paragraph (4) of the Bankruptcy Act is no longer implementable and a court order is needed.

The next question is the procedures in filing a bankruptcy petition by Bank Indonesia and the Ministry of Finance given that the function, duties, and authorities specified in Article 55 of the Financial Services Authority Act has been transferred to the Financial Services Authority. To answer this question the author analyzes that with the transfer of duties and function to the Financial Services Authority as stipulated under Article 55, it does not mean that the Financial Services Authority does not have an inter-institutional relationship with Bank Indonesia and the Minister of Finance. Article 39 of the Financial Services Authority Act regulates that the Authority still coordinates and cooperates with Bank Indonesia in terms of formulating regulations on the supervision of the banking sector, which include among others:

a. Bank's minimum capital requirement;

b. An integrated banking information system;

c. Policies in the admission of funds from other countries, admission of foreign currencies, and foreign commercial loan;

d. Banking products, derivate products and other bank business activities;

e. Determination of banking institutions that are included into the category of systematically important banks; and

f. Other data excluded from the provision on the confidentiality of information.

In addition to coordinating the above, the Financial Services Authority and Bank Indonesia also coordinate and cooperates in other matters. For example if Bank Indonesia requires a special examination to be conducted towards certain banks, then Bank Indoensia may conduct direct examinations of that bank by giving prior written notice to the Financial Services Authority. The examination report must be delivered to the Financial
Services Authority no later than 1 (one) month since the report was issued. However, in this respect, Bank Indonesia may not provide assessments towards the soundness of banks. ${ }^{20}$ In the event the Financial Services Authority indicates that certain banks experience difficulties in liquidity and/or the condition of health has worsened, the Financial Services Authority must immediately inform Bank Indonesia to take measures in accordance to its authority. ${ }^{21}$

According to the aforementioned provisions, it can be concluded that the Financial Services Authority still coordinates and cooperates with Bank Indonesia and the Minister of Finance, including filing for a petition of bankruptcy. To further shred light on the matter, this will be elaborated in the following passage:

a. In the event the debtor is a bank, the authority to petition for a declaration of bankruptcy is still held by Bank Indonesia. However, Bank Indonesia coordinates with the Financial Services Authority, by way of informing the Financial Services Authority through a written notification letter that there are banks which will be filed for a bankruptcy petition. Bank Indonesia must also put together a written report to the Financial Services Authority on the situation and development throughout the bankruptcy process.

b. In the event the Debtor is an insurance company, reinsurance compay, pension funds, and state-owned enterpreises engaged in the sector of public interest, th authority to file a bankruptcy petition is held by the Minister of Finance. Similar to Bank Indonesia, the Minister of Finance must also coordinate with the Financial Services Authority informing them through

\footnotetext{
20 See Article 40 Act No. 21 of 2011 concerning the Financial Services Authority.

21 Article 41 paragraph (2) Act No. 21 of 2011 concerning the Financial Services Authority.
} 
a written notice and also submitting

a written report on everything that occurs in the bankruptcy process.

c. In the event the Debtor is in the form of securities companies, stock exchange, clearing and custodian institutions, settlement and depository institution, the authority to file a petition for bankruptcy is be determined by a judge. This is because the Capital Market Supervisory Board has amalgamated into the Financial Services Authority, therefore the Board's institutional form no longer exists.

\section{Conclusions}

Through Article 55 Act No. 21 of 2011, the Financial Services Authority has taken over the duties, functions, and authority in regulating and supervising the financial services sector from the Minister of Finance, the Capital Market Advosry Board, and Bank Indonesia. However, the Financial Services Authority Act does not determine explicitly whether the transfer includes also the right to file bankruptcy petitions. Bankruptcy cases, are categorized as special civil cases (lex specialis) conducted to settle disputes over debt. If a debtor who cannot pay its debts and a bankruptcy petition is filed to the commercial court, the case subjects itself to Act No. 37 of 2004 concerning Bankruptcy and Suspension of the Obligation for Payment of Debts. Therefore is a debtor is a Bank then in accordance to Article 2 paragraph (3) of the Bankruptcy Act, the institution having valid legal standing as the bankruptcy applicant is Bank Indonesia. However Bank Indonesia must coordinate with the Financial Services Authority by informing them through a written letter of notice informing them of the bank which will be filed for bankruptcy. Bank Indonesia must furthermore draft a written report to the Financial Services Authority on the situation and development throughout the bankruptcy process. In the event the debtors are in the form of insurance companies, reinsurance companies, pension funds, and state-owned enterprises engaged in the sector of public interest, whereby according to Article 2 paragraph (5) of the Bankruptcy Act, the institution that has valid legal standing is still held by the Minister of Finance. Similar to how the rule applies to Bank Indonesia, the Minister of Finance must also coordinate with the Financial Services Authority by informing them through a written letter of notice informing them of the bank which will be filed for bankruptcy and later on draft a written report to the Financial Services Authority on the development of the bankruptcy process. Specifically for when the Debtor is in the form of securities companies, stock exchange, clearing and custodian institutions, settlement and depository institution, the authority to file a petition for bankruptcy is be determined by a judge. This is because the Capital Market Supervisory Board has amalgamated into the Financial Services Authority, therefore the Board's institutional form no longer exists. Thus, Article 2 paragraph (4) of the Bankruptcy Act can no longer be implemented and a court order is necessary for filing bankruptcy petition against institutions stated within the Article.

\section{BIBILIOGRAPHY}

\section{A. Books}

Harjono, 2008, Konstitusi sebagai Rumah Bangsa Pemikiran Hukum Dr. Harjono, S.H., M.C.L. Wakil Ketua MK, Sekretariat Jenderal dan Kepaniteraan Mahkamah Konstitusi, Jakarta.

Hartini, Rahayu, 2008, Penyelesaian Sengketa Kepailitan di Indonesia, Prenada Media,
Jakarta.

Ibrahim, Johnny, 2006, Penelitian Hukum Normatif, Tribisana Karya, Jakarta.

Muljadi, Kartini dan Widjaja, Gunawan, 2005, Pedoman Menangani Perkara KepailitanEdisi Revisi, Raja Grafindo Persada, Jakarta. 


\section{B. Legislations}

Act No. 21 of 2011 concerning the Financial Services Authority.

Act No. 37 of 2004 concerning Bankruptcy and Suspension of the Obligation for Payment of Debts.

Bank Indonesia Regulation No. 16/11/PBI/2014 concerning Macroprudention Regulation and Supervision.

\section{Internet Articles}

Mahendra, A.A. Oka, "Disharmonisasi Antar Peraturan Perundang-undangan", $w w w$. ditjendpp.kemenkumham.go.id, accessed on 5 October 2014. 